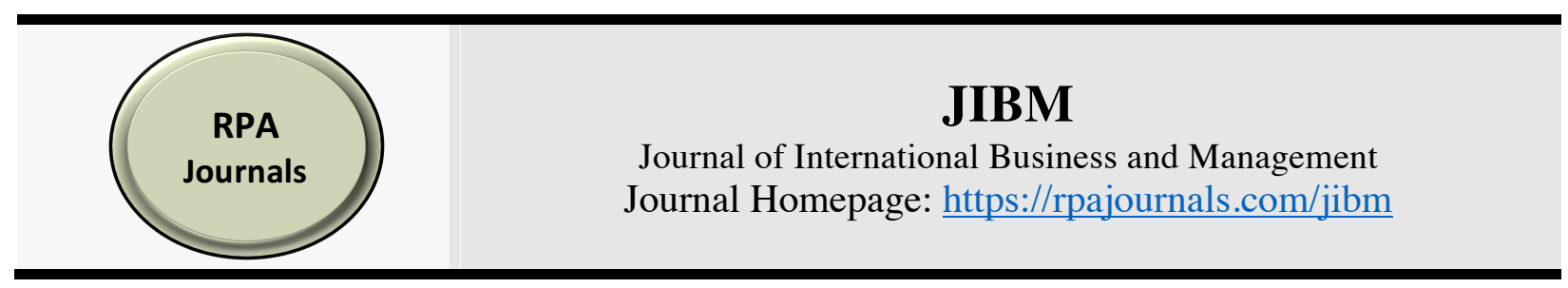

\title{
Exploring the Role of Soft Skills in Advancing the Employability of Business Graduates in Bangladesh
}

\author{
Sabreya Khanom Zuma \\ Ahsanullah University of Science and Technology, Bangladesh
}

\begin{abstract}
Soft skills are of utmost importance in the workplace because they set the tone for how people perceive someone and also give the chances of building relationship with co-workers. The aim of this study is to explore the salient role of soft skills possessed by business graduates on their employment opportunity. In this regard, nine different soft skills have been selected for analyzing the employability of business graduates. The primary data have been collected from 359 business graduates through floating a structured questionnaire. Five-point Likert measurement scale has been used to measure the data which were eventually analyzed through descriptive statistics. Bivariate correlation is applied to realize the interaction among different soft skills toward the enhancement of employability. Therefore, the analytical results have been revealed that the adaptability to work environment is the most influential soft skills. Then interpersonal qualities and good communication skills are consecutively remarkable. Besides, the family and selflearning are playing significant role in develop soft skills. Moreover, the findings of the study infer that the acquiring and practicing soft skills from family to professional life have a great impact to achieve alluring employment opportunities for the business graduates.
\end{abstract}

Keywords: Soft Skills, Employability, Business Graduates, Bangladesh.

*Corresponding author: Sabreya Khanom Zuma; Email: sabreyazuma@gmail.com

DOI: https://doi.org/10.37227/JIBM-2021-01-122

\section{Introduction}

In the present competitive job market, if business graduates want to prove themselves competent then they must hold some competencies and those competencies can be earned through soft skills. Because the employers are becoming more interested to choose a candidate having soft or non-technical skills apart from the academic education (Mansour and Dean, 2016). There is a high demand of candidates who have soft skills mostly preferred by the corporate recruiters (Robles, 2012). Soft skills are associated to build a rich career path and its effective practice make sure the individual performance enhancement (Sangamitra and Priya, 2015). Truong and Laura (2015) opined, without the acquisition of "soft skills," the potential success in the context of international trade, business and productivity can't be achieved. In addition, soft skills are treated as one of the essential elements in the total quality management in today's business world (Fotopoulos \& Psomas, 2008).

Soft skills are getting more acceptance due to improve the personal development, participation in learning and success in employment (Gibb, 2014). Soft skills indicate to the positive attributes, competencies, skills, personality traits, behaviour apart from technical knowledge. Meenu and Kumar (2009), soft skills are also called transferable skills that complement as 'hard skills'; 'academic skills' or 'technical skills'. Global research feedback shows that soft skills are far more important for career success especially in the business arena. Approximately $70-80 \%$ of an 
individual's career success depends on the value addition by soft skills and remaining $15-30 \%$ for hard skills or technical knowledge (Hommerichhousen, 2002; Klaus, 2010; Watts \& Watts, 2008).

Typically, the academic education of Bangladesh especially in the university level extremely emphasize on acquiring hard skills. But only acquisition of hard skills is not enough for today's knowledge based economy and even it can't prove that a graduate would be a good employee in future alone with hard skills. In this competitive context, the curriculum of business program both of public and private universities must endeavour to develop creative and innovative ways to provide soft skill training for their students which are specially designed to enhance their competitive edge (Jamison, 2010). Thus, business graduates can add more trendy values to the organization using their technical aptitudes and theoretical knowledge through soft skills and it will help them to secure a stable position (Wheeler, 2016).

The aim of this paper is to explore the significant role of soft skills by examine their effects on graduates' employability and provide a content of which soft skills are mostly preferred by business graduates according to the demand of employers. This study has covered nine different soft skills inspired by the study model Common Employability Skills Framework by (National Network of Business and Industry Associations, 2014) which was adopted partially. The high quality workforce who effectively deploy soft skills along hard skills will significantly improve the chance of success in the trading competitiveness to the business enterprises and it is playing an integral role in business world now (Payne, 2000; Grugulis, 2003; Tamkin, 2007). Several studies have been conducted on soft skills but this study mainly focus on identifying the correlation among soft skills and employability and also it shows the most preferred and practiced soft skills of business graduates in Bangladesh.

This study attempts to recognize the most demanded soft skills for business graduates according to the preferences of employers, universities' academic education should accommodate those required skills and minimize the skills gap between academic skills knowledge and nontechnical skills in the workplace. In this regard, the descriptive statistics has been done to show the skills preferences by the fresh and employed business graduates. The correlation covers the relationship among the selected soft skills and even on employability. Therefore, the significant role players to develop the soft skills in a business graduates have also been found out. Hopefully this study will help the business graduates for being equipped during and after graduation regarding the soft skills to pursue desired employment and become more competent.

\section{Literature Review}

Soft skills make a graduate capable for entering into the job market but most of the graduates feel that after academic degree they are ready enough to start job (Erni and Suhana, 2015). But in real life, most of the qualities possessed by fresh graduates are not matched according to their expectations (Tharunya and Kottawatta, 2014). The curriculum of business education should be designed to assist with the integration of interpersonal skills (Mitchell, 2010). The research study found that the typical learning styles of all students are not basically meet the need of soft skills. So, to meet the work related effective soft skills required by the employer, a graduate can follow the model given by Common Employability Skills Framework by (National Network of Business and Industry Associations, 2014). Haws (2002) said that to prepare the students for the global marketplace there are need of five critical success factors such as communication abilities, interpersonal skills, creative problem solving, ethics education, and technological and analytical competences and integrate these factors throughout the business curriculum.

The trend of the soft skills doesn't remain same around the decade, that's why it is needed to be updated according to the time demand. Today's soft skills may become obsolete tomorrow. Similarly, the quality of academic education of the universities remained same for decade but very poor return from the workplace performance (Shah, 2015). Thus, they are not confident enough in the area of professional management skills (Wang and Tsai, 2014). Hazzan and Har-Shai (2013) said that soft skills cannot be formally studied and taught rather, should be learned over a period of time based on students' engagement, active learning, and reflection. So, the employability skills required 
by employers are interpersonal relations, coping with emotions, self-awareness, and empathy and if a graduate has all these skills, he/she will be able to work within group (Al-Alawneh, 2014).

The acquisition and practice of soft skills are increasing day by day due the rise of employability competencies in the competitive job markets. According to the demand of employers, the graduates need to make them capable with soft skills so that they can easily mitigate the job challenges. Although several researches have been conducted on the soft skills development in both developed and developing countries, whereas most of the researchers focused on identifying different soft skills which have importance for enhancing the employability of students. But very few researches were conducted to know the affecting soft skills on graduates' employability as well as the key role players to develop those. Therefore, this study endeavours to find out the most preferred soft skills by Bangladeshi business graduates and the influential role players for building these skills. The following soft skills have been focused in this study:

\section{Problem-Solving}

Problem-solving skill is a combination of using both analytical and creative thinking to find solutions and it includes logical reasoning, analysis, lateral thinking, initiative, persistence, observation, persuasion, negotiation, brainstorming and decision making (Chaudhury, 2008). Rather it is a mental habit that requires students need to use their higher-order thinking skills except what they actually are taught to read or typical memorizing data without critically thinking about it (Scriven \& Paul, 2008). Even, the creative movement skills and strong awareness about it push the pre-schoolers' problem-solving capability (Marigliano and Russo, 2011). However, the reformation of typical education system and perception of teachers on critical thinking have a great influence on shaping the students' problem-solving capacity (Innabi and Sheikh, 2007). Because the current educational trend just focuses on examination scores which may undermines the critical thinking at the classroom (Landsman \& Gorski, 2007; Sandholtz, Ogawa, \& Scribner, 2004; Wong, 2007). Snyder \& Snyder, (2008) found that there are four barriers that obstruct the critical thinking in education: (i) lack of training, (ii) lack of information, (iii) preconceptions, and (iv) time constraints. It is because most of the time teachers don't get sufficient training regarding the critical thinking methodologies (Broadbear, 2003). Thus, Hemming (2000) pointed that students need to know how to think critically before applying skills and also, they should be given enough freedom to explore study contents, effectively using resources and applying information.

\section{Interpersonal Skills}

Interpersonal skills are those that you use to interact and communicate with colleagues and superiors by sensitivity, empathy, humour, mentoring, networking, patience, tolerance, public speaking, positive reinforcement and diplomacy. Applicants who have interpersonal skills are treated as the competitive advantage for becoming successful organization (Glenn, 2008; and Mitchell, 2010). American Management Association (2012) has conducted a survey on 768 managers and executives where majority believed that core competencies like collaboration and communication are essential for the effective job performance and strong degree of these ensure the increased interaction with others along interpersonal competence (Bedwell, Wildman, DiazGrana-dos, Salazar, Kramer, \& Salas, 2012). In this regard, Claxton (2016) recommended that interpersonal skills are the precondition for successful careers. Moreover, the burden goes to the many universities of U.S. who acknowledge the lacking of interpersonal skills in their academic courses (Abraham \& Karns, 2009). Latham, Latham, \&Whyte (2004) found that the MBA graduates who have exceptional technical knowledge but lack of the ability for being team players may be reported for failure in career. But unfortunately, the solution is not simple a couldn't get overnight due to the overload of existing courses by integrating more interpersonal skills related courses (Bedwell, Fiore \& Salas, 2014). Although some attempts are getting appreciation like Chicago's Booth, Northwestern University's Kellogg, Wharton School of the University of Pennsylvania, Yale School of Management offer organizational behavior course focusing on especially leadership, critical thinking and communication (Datar, Garvin, and Cullen, 2010). 


\section{Creativity}

Creativity skills help to develop innovative solutions to problems at work that have a great impact on the firm's overall performance, product and process innovations and community building (Kachelmeier, 2008, Weinzimmer, 2011, Ahlin, 2014). Sometimes, it depends on the culture and climate of the organization (Hoegl, 2012). It also has the influential effect on the career growth of business students (Fekula, 2011 and Kerr \& Lloyd, 2008). However, some researchers have found that business students are relatively lacking behind in the race of creativity ratings than other disciplines' students. For instance, Wang, Peck, and Chern (2010) showed that business students hold pointedly lower scores than design students in generating creative ideas, ability to shift one idea to another in the change perspective and uncommon ideas with enough elaboration. Another study conducted by Schlee, Curren, Harich, and Kiesler, (2007) focused on the most likely the marketing students were considered as more creative perfectly $(55 \%)$ comparing to management students (41\%), finance students (32\%), accounting students (31\%), and economics students ( $25 \%$ only. So, the solution can be offered with some training for new idea generation incorporating the brain storming and developing multiple creative thinking components (Armstrong \& Kotler, 2012; Kerin, Hartley, \& Rudelius, 2012).

\section{Communication}

Communication is one of the influential soft skills in today's global business environment (John, 2009; and Timm, 2005). It is also defined as a process to understand the environment with nonconscious, semi-conscious and conscious ways (Salleh, Sulaiman, Mohamad \& Sern, 2017). National Association of Colleges and Employers (2001) agreed that communication skill is one of the essential requirements for students' eventual career success. Usually it is assumed that everyone knows it very well and does well. But unfortunately, that assumption is not a reality rather the lacking of proper communication is the witness of many tragedies and disasters in the wider environment of recent years (Jelphs, 2006). As a result, business graduates are often found as perceived as inadequate at the entry level of their job regarding communication skills (Brodowsky and Anderson, 2003 and Gray, 2010). The gap is found as the lacking of focus in business education curriculum about skills relating to the practical use avoiding only theoretical understanding or abstract knowledge (Pfeffer and Fong, 2002). Actually, it is happened due the gap in between the thought of business academician and employers' expectations about the business graduates' readiness for post-graduation employment (Sapp and Zhang, 2009). Usually, business graduates are not so competent in writing ability which is the great hinderance toward their career progress (Anderson and Bacon, 2004). But the academic learning should be outcome based and real-world standard that what actually the employers want (Kerby and Romine, 2009 and Pittenger, Miller and Mott, 2004). Moreover, Young and Murphy (2003) suggested to add academic research, receiving consistent feedback from employers, college recruiters, and alumni to enrich the communication skills for marketing students.

\section{Work Ethics}

The work ethics directly affect the entire business environment so that business ethics discipline is taught in business schools at both the undergraduate and graduate levels to help students and employees understanding the importance of honesty and ethics (Gentile 2010). Other scholars have focused on teaching business students about the interrelationship between business and society (Harris 2008; Freeman, 2009). Crane (2004) surveyed on MBA students to know their attitudes toward business ethics and finally they agreed that it has immense importance to the academic community. Likely, other institutions such as Association to Advance Collegiate Schools of Business (AACSB international, 2012) and Academy of Management emphasized that the ethical value practice and ethical decision making should be taught to the business students considering in business decisions and they should be trained properly regarding this. One of the studies conducted by Beeri (2013) presents that the awareness regarding the code of ethics has been increased immensely after the implementation of ethical programs on the regional council of Israel. The practice should be started from the academic teaching, research and training for students (Petrick, 2011). If there is the absence of ethical value practice, the business students can be transmitted into unethical practices 
due to the ruthless nature of our competitive economy and that's why business programs need to integrate business ethics into the academic curriculum for effective learning (McDonald, 2004 and Sims, 2002). Hence, it is proven by one of the empirical studies that the introduction to business ethics into the classroom may increase the ethical sensitivity, behaviour and moral reasoning to the students (Lowry, 2003 and Sims et. al., 2002).

\section{Teamwork}

Teamwork has a great effect on the performance and effectiveness of an organization when the team members have abilities, knowledge, and skills (Hanaysha, 2016). Gerhardt (2019) studied on the proficiency of soft skills towards employability among students by a research. Total 221 respondents supported that teamwork positively affects the employment of graduated students. Another research conducted by Riebe, Roepen, Santarelli, and Marchioro, (2010) to find out the effectiveness of university programme in teaching the students about teamwork skills and future employment. For instance, a special emphasis has been given to the higher education curricular (Chapman, Meuter, Toy, \& Wright, 2010). Not surprisingly, a national survey conducted by Hart Research Associates (2009) on colleges and universities of U.S. found that about $71 \%$ of respondents supported to enhance the teamwork skills at the school level. One of the biggest barriers behind the poor teamwork skill development into the students is weedy assessment or measurement scale of teamwork performance (Hughes \& Jones, 2011). Simply forming the team, assigning project works without providing functional guidance, using paper and pencil tests, rely on inappropriate grading system for evaluation, absence of direct observation, coaching and skill development are some common reasons of failure of typical teamwork for business graduates (Ettington \& Camp, 2002; and Hansen, 2006). Hence, the direct observation of students' performance and using empirical scale of performance measurement would be very effective to build sustainable teamwork (Hughes \& Jones et. al., 2011).

\section{Adaptability}

Adaptability is considered as the relationship between employees' change-related uncertainty and employees' satisfaction of performance (Cullen, 2014). Indeed, career adaptability represents the knowledge, skills, abilities and willingness to handle career challenges with potential career development activities through transitions and finding suitable employment (Koen, 2012 and Savickas \& Porfeli, 2012). Usually, when students transit from university to workplace, they fall into a daunting experience due to fierce competitive in the job market, entering into inappropriate job initially, far away from home, lack of employability skills, limited working experience, excessive workload and financial shortage (Helyer \& Lee, 2014; Koen et.al., 2012; Robotham \& Julian, 2006; and Shahbaz, 2016). In this regard, several researchers have suggested that proactive personality and behavior assist the students to focus on future career growth, be self-concerned, confident, seeking self-improvement, identifying potential opportunities and which ensure their effective transition from academic institutions to employment (Bateman \& Crant,1993; and Koen et al., 2012). Some of them also have identified the positive relationship between proactive personality and career adaptability (e.g., Cai, 2015; Jiang, 2017; and Öncel, 2014).

\section{Time Management}

A correct management of time leads to better results, being more efficient the individuals who set goals and objectives, as well as priorities; or individuals who have received training in time management, and are generally more prone to planning (Hellsten, 2012). Therefore, the time management skill should be started from school and enriched by experience. Also, it is the combination of learning behaviors and habits that lead to increased knowledge, training, or practice (MacCann, 2012, p. 619). Indeed, the university plays a significant role to make the students time management competent for future professional world. During academic life, students get equipped with more transformed way of thinking integrating time management skills (Shayanka, 2016, p. 493). On the contrary, lower performance is the reason of time lacking which creates a negative impact on the psychological resources of individuals (DTI, 2001). Hashemizadeh (2006) focuses on the optimal 
use of time in order to live a better and easier life that includes personal skills, goal setting and organization of activities.

\section{Leadership}

Leadership is the art of motivating a group of people to achieve a common goal (Sheriff, 2017). The perspective of the leaders and the leadership development activities such as project management, empathy, selflessness, agility, listening, humility, cultural intelligence, authenticity, versatility, generosity and trust can influence the employability rate among graduates (Nolan-Arañez and Ludvik 2018, Crowne, 2019). Several researchers have supported that leadership skills are essential for understanding the work environment and situational problem-solving (Thompson \& Miller, 2018; Bell, Anderson, Conner, \& Severance, 2016; and Lord and Hall, 2005). Indeed, leadership skills are not so easy to learn instant and even by the traditional education methods such as descriptive lectures, course books or some specific definitions rather it could be earned by the practical experience or project works done by the students. Even, leadership styles and practice vary from the contingent contexts that need realistic and problem-solving learning environment which lead to successful leadership (Day, 2001). It assists the students for managing complex situations during their academic life and also the business running practices for professionals with in depth understandings (Shaffer (2004). Moreover, Gerhardt (2019) said that there is a close intervention between students' leadership and their confidence in employment.

\section{Employability}

Employability skills are the set of essential skills and behaviours that are transferrable to many jobs (Robles, 2012). It is becoming the integral part for job candidates. So that it is generating widespread academic interest among higher education providers (Artess, 2017). The immense importance of soft skills in business education has been recognized by The National Network of Business and Industry Associations (2014). They detail employability skills in a four-dimensional framework including personal skills, people skills, applied knowledge, workplace skills which express their importance not only for the employment itself but also for the success in all labour market sectors. The pedagogical approach by Yorke shows the wide spectrum which includes employability skills are the set of achievements such as skills, understandings and personal attributes that makes graduates more likely to gain employment and to be successful in their chosen occupations, which benefits themselves, the workforce, the community and the economy (Yorke, 2006).

\section{Role Players in Developing Soft Skills}

We believe that academic learning is influential factor for developing soft skills which is proven by one of the studies conducted by Mansell in a school in Great Britain, where students were involved to measure their soft skills with teamwork, various assignments, research projects, and presentations (Mansell, 2006). On the contrary, one of the researches from Majid, Liming, Tong, and Raihana (2014) shows that about $55.1 \%$ of the respondents agreed with the suggestion that soft skills are difficult to learn compared to professional knowledge and skills. Along with the academic education, family learning, friends \& mates and even different social stakeholders play significant role in soft skills development where they can learn norms, values, and etiquettes that are widely accepted. Besides, soft skills can also be enriched at the workplace with the influences of supervisors, colleagues and the learning environment (Robles, 2012; Taylor, 2016).

\section{Research Methodology}

To conduct the survey regarding the perceptions of business graduates about soft skills, a structured questionnaire has been distributed among 400 fresh, blue and white collar employed business graduates in Bangladesh who are involved in several types of corporate and academic professions. However, $89.75 \%$ or 359 participated and responded to the survey, hence selected as the sample of the study and the convenient sampling technique has been applied. This research has been developed on the basis of Common Employability Skills Framework by (National Network of Business and 
Industry Associations, 2014), which was partially adopted and the variables are also sourced from the empirical study ModEs European Project conducted by Haselberger, (2012). In addition to the questionnaire includes adaptability, work ethics, team work, communication and problem solving. Total 9 items have been included at questionnaire corresponding to soft skills along with the demographic background of the graduates (gender, age, study year, major, experience and professional degree). In terms of gender, female group predominates in the study about $57.9 \%$ ). The questionnaires were spread over online especially by the means of email and even through social media. The items were assessed using Likert measurement scale of 5- point (Likert, 1961), where 1 is strongly disagree and 5 is strongly agree. The primary data have been analysed with SPSS statistics and the data quality metrics was calculated through Cronbach's Alpha. The coefficient $(\alpha=.703)$ indicates the standard internal consistency of the questionnaire (Hair, Sarstedt, Ringle, and Mena, 2012). Descriptive statistics is applied first to screen the data and find out mean and standard deviation. Furthermore, the Pearson correlation analysis is conducted to know the relationship among different soft skills on employability enhancement.

\section{Results and Analysis}

Overall, the descriptive statistics analysis shows that the most of the business graduates of Bangladesh highly emphasize on the adaptability or optimistic adjustment to the workplace which carries the mean of 4.9526 and standard deviation of 0.2806 . They opined that interpersonal skills are similarly very significant role player to make an employee acceptable to the employment so that it bears the mean of 4.9304 and standard deviation of 0.3226 . Sequentially, prioritized soft skills are communication $($ Mean $=4.5125$, St. Dev. $=.8284)$, time management $($ Mean $=4.2145$, St. Dev. $=$ $.9951)$, leadership $($ Mean $=4.1588$, St. Dev. $=.9542)$ and approximate values are carried out by problem solving, work ethics, team work and creativity.

Table 1: The Descriptive Statistics of Studied Constructs

\begin{tabular}{|l|c|c|}
\hline & Mean & Std. Deviation \\
\hline Problem solving & 3.6128 & .8276 \\
\hline Interpersonal skills & 4.9304 & .3226 \\
\hline Creativity & 3.2758 & .8902 \\
\hline Communication & 4.5125 & .8284 \\
\hline Work Ethics & 3.4318 & .9832 \\
\hline Team work & 3.3315 & .9329 \\
\hline Adaptability & 4.9526 & .2806 \\
\hline Time management & 4.2145 & .9951 \\
\hline Leadership & 4.1588 & .9542 \\
\hline Valid N (listwise) & & \\
\hline
\end{tabular}

Correlation analysis highlights the relationship among the variables with the significance levels of $\mathrm{p} \leq 0.01$ and $\mathrm{p} \leq 0.05$. The significant relationships have been found with leadership, adaptability, team work, time management, creativity and $\mathrm{r}=.383, .366, .219, .213$ and .176 respectively. 
Table 2: The Correlation Matrix of Studied Constructs

\begin{tabular}{|c|c|c|c|c|c|c|c|c|c|c|}
\hline & 1 & 2 & 3 & 4 & 5 & 6 & 7 & 8 & 9 & 10 \\
\hline 1. Problem Solving & 1 & & & & & & & & & \\
\hline 2. Interpersonal Skills & -.017 & 1 & & & & & & & & \\
\hline 3. Creativity & -.030 & .031 & 1 & & & & & & & \\
\hline 4. Communication & .004 & .034 & $.454^{* *}$ & 1 & & & & & & \\
\hline 5. Work Ethics & .007 & -.033 & $.326^{* *}$ & $.300^{* *}$ & 1 & & & & & \\
\hline 6. Team Work & -.001 & .060 & $.561^{* *}$ & $.425^{* *}$ & $.421^{* *}$ & 1 & & & & \\
\hline 7. Adaptability & .085 & .021 & $.409^{* *}$ & $.297^{* *}$ & $.308^{* *}$ & $.519^{* *}$ & 1 & & & \\
\hline 8. Time Management & -.006 & .028 & $.211^{* *}$ & $.141^{* *}$ & .017 & $.187^{* *}$ & $.313^{* *}$ & 1 & & \\
\hline 9. Leadership & .070 & -.022 & .059 & -.005 & .085 & $.140^{* *}$ & $.331^{* *}$ & $.175^{* *}$ & 1 & \\
\hline 10. Employability & .029 & .011 & $.176^{* *}$ & .131 & .069 & $.219^{* *}$ & $.336^{* *}$ & $.213^{* *}$ & $.383^{* *}$ & 1 \\
\hline
\end{tabular}

The correlation result indicates the significant relationship between leadership skill and employability with $\mathrm{r}=0.383$ and $\mathrm{P}-$ Value $=0.000(\mathrm{P} \leq 0.001)$. Also, it can be said that $15 \%\left(0.383^{2}\right)$ of the variation in leadership skills in a graduate may influence positively the employability. Hence, business graduates realize that the effective leadership skills can help them to think in a unique and out-of-box ways. So, to build up good leadership skills the students should be inspired to taking initiatives, developing good character and self-confidence. Similarly, the adaptability or positive adjustment to the workplace has greater value on employability $(p=.000, r=.336)$. this skill is the combination of several valuable qualities that someone can show his/her ability to be resourceful with strong determination and dedication.

Consequently, there is significant relationship between team work and employability with $r$ $=0.219$ and $\mathrm{P}$-Value $=0.000(\mathrm{P} \leq 0.001)$. Also, it can be said that $4.8 \%\left(0.219^{2}\right)$ variation of working in a team may have positive impact on employability. Working in team may bring some valuable outcomes like creativity and learning opportunities, complementary strengths, trust to each other, conflict resolution techniques and so on. Therefore, the time management skill to prioritize the work has greater value on employability bearing $(\mathrm{p}=.000, \mathrm{r}=.213)$ or $4.5 \%\left(0.213^{2}\right)$. It will help to accomplish more tasks in a shorter period of time, taking advantage of learning opportunities, lowering the work stress and helps to focus on more career success.

Thus, the relationship between creativity and employability is significant with $r=0.176$ and $\mathrm{P}$-Value $=0.000(\mathrm{P} \leq 0.001)$. There is $3 \%\left(0.176^{2}\right)$ of the variation in creativity skill in a graduate may influence positively the employability. It encourages more collaboration at workplace with creative thinking, team bonding, problem solving and increasing productivity.

On the other hand, insignificant relationship is explored by communication, work ethics, problem solving and interpersonal skills with the value of $(p=.013, r=.131),(p=.190, r=.069),(p$ $=.578, \mathrm{r}=.029)$ and $(\mathrm{p}=.833, \mathrm{r}=.011)$ sequentially corresponding to employability. The business graduates should possess good communication skills so that they can listen as well as speak out. The explicit exposure of sharing knowledge will assist the graduates to express themselves at the interview board to attract recruiters, also be a good listener and at asking questions. The successful career is also depended upon the proper maintenance of integrity at workplace, analytical ability to find out solutions and good interpersonal skills for the effective interaction with others.

\section{Role Players to Develop the Soft Skill?}

The result reveals that the family learning has the highest impact on developing soft skills because family learning is the life-long lesson into a human being. Besides, self-learning is the second most influential factor without which one can't acquire new knowledge and implement in the real life. The outcome of two variables family learning and self-learning are nearly similar with the mean of 4.9499 $\& 4.9443$ and standard deviation of $0.2751 \& 0.3031$ respectively. Moreover, prolong academic education also helps a person to become more sensible, responsible, ethical, potential professional 
and so on. It includes the mean of 4.3760 and standard deviation of 0.3310 . Furthermore, when entering into the professional life, some people get very appreciable changes due to their employer's grooming. So, on-the-job or off-the-job nursing from employer is another influential role player having the mean of 4.4949 and standard deviation of 0.3120. Along with professional institutions, friends \& classmates and peer/colleagues have parallel values of mean 3.6330, $3.5766 \& 3.4735$ and standard deviation of $0.5987,0.8743$ and 0.9477 consecutively.

Table 3: The Role Players for Developing Soft Skills

\begin{tabular}{|l|c|c|}
\hline \multicolumn{1}{|c|}{ Role Players } & Mean & Std. Deviation \\
\hline Self-Learning & 4.9443 & .3031 \\
\hline Family Learning & 4.9499 & .2751 \\
\hline Academic Education & 4.3760 & .3310 \\
\hline Friends \& Classmates & 3.5766 & .8743 \\
\hline Professional Institution & 3.6330 & .5987 \\
\hline Employer & 4.4949 & .3120 \\
\hline Peer/Colleagues & 3.4735 & .9477 \\
\hline
\end{tabular}

Meanwhile, Taylor (2016) has explored that the soft skills development largely depends on different learning exposures. These learning exposures can be generated from the individual efforts and the social institutions (Robles et. al., 2012). Because the outcome of these learnings (e.g., soft skills) can vitally contribute to the accelerating individual career growth and enriching social standard of living (Taylor et. al., 2016; Colman and Willmot, 2016). In addition, the findings of this study found that family is the most influential role player in developing soft skills. Hence, family is the primary learning institution where an individual can develop the sense of friendship, love, interpersonal relationships, cooperation, good behaviour, discipline, and recognition of authority (Hasbulloh, 2011). Besides, self-learning leads to greater self-knowledge with profound experiences and helps to acquire multiple skills by improving personal relationships and exploring more avenues of career growth (Turner, 2020). If there is no practice and self-motivation to create own urge to learn new something that would lead the person behind the race of career progress.

Apart from this, a gigantic responsibility goes to the academic institutions for contributing to students' life regarding soft skills development. The typical curriculum of business education in Bangladesh holds lecturing, cramming and examination. But that all have been barely changed for centuries and universities' business schools are facing challenges of unprepared graduates to enter into the job market (Bennis and O'Toole, 2005; Dunne and Martin, 2006). Behind the traditional courses of university, they should move for an authentic learning method containing practical and project-based education (Herrington, 2010). Academic orientation assists them to earn leadership quality, communication, team work, adaptability, grooming for taking responsibility, being presentable with proactivity and growing emotional intelligence. After entering into the professional arena, freshers are got heavily influenced by the employers, supervisors, peers or colleagues and even the learning environment (Robles et. al., 2012; Taylor et. al., 2016). Often employers can arrange soft skills training such as eLearning, periodic feedback, seminars, discussion, role playing and team building activities which may improve their career (Pereira and Costa, 2017). Along the professional learning during the career enable the graduates to handle unpredictable complexities at the workplace (Schön, 1987). Moreover, it is a common phenomenon in Bangladesh that graduates actually receive non-technical education during their academic life and mostly dependent upon the professional learning as well as employers with the expectations of career blooming up.

\section{Discussion}

It has been revealed by this study that soft skills have very strong correlation to employability of business graduates in Bangladesh. It assists people to get adjusted with the work and positively behaving to professional challenges effectively every day and also helps to acquire the job competencies. Because job competency is the combination of different soft skills which may bring 
the job-fit attribute to employees and superior performance (Boyatzis, 2008). Hence, the findings of this study get similarity with some previous researches such as soft skills adopted students are capable of taking effective initiatives, successfully cope-up with organizational culture and contribute to organizational success (Harvey, 2000). Not only the individual or group of researchers agreed but also different institutions pointed that soft skills are closely connected to enhancing the employability of students especially for the young who are recently entering into the job market after graduation (European Commission, 2012a, b,2013; Grugulis and Vincent, 2009; ISFOL, 2012). Similarly, Succi (2019) found that the soft skills learning makes the students ready to find the best job-fit. Thus, several previous survey results support the same findings such as soft skills are changeable in nature due the ever-changing business environment and graduates must learn to be new initiative taker, attentive listener, good communicator to deal with diverse personalities, critically think and problem solving and managing time effectively (Apparaju, 2016; Kleckner and Marshall, 2014; and Messum, 2015). Again, Nusrat, \& Sultana, (2019) presents in their study that soft skills closely interpret the employability of business graduates. So, it collectively agreed that soft skills are needed to be practiced in personal and professional life for the betterment of graduate's future progressive career life.

The results of the study show that the most of respondents opined the adaptability, interpersonal skills, communication, time management and leadership quality are the most required skills for earning employability with the scale of preferences, mean 4.9526, 4.9304, 4.5125, 4.2145 and 4.1588 consecutively. The overall scenario highlights that adjustment to the workplace and effective adaptability is required for the long survival and sustainability. Similarly, different interpersonal skills help the graduate to make a mutually understanding working environment by establishing mutual respect to each other. Besides, good communication ensures the ability to give responses and receive audiences' feedback effectively and also resolve actual and potential problems among concerned parties. Also, the time management skills enable graduates to make effective structure of their work, prioritize the tasks, allow to accomplish those in more creative and proactive ways toward the goals. Along with the correlation analysis represents the strongest relation of employability with leadership, adaptability, team work, time management and creativity including the ' $r$ ' value; $r=.383, .336, .219, .213$ and .176 with the $1 \%$ significance level. Moreover, the respondents pointed out that there are some stakeholders who are very responsible to build such soft skills into the students' lives. Even they would take part at any spheres of student's life and contribute to the personal as well as the professional skills building. This study reveals the basic learning from the family and family members are the most responsible concern with the mean of 4.9499 , then selfmotivation or self-learning of graduate (4.9443), employer (4.4949), academic education (4.3760), professional institutions (3.6330), friends/classmates (3.5766) and colleagues/peers (3.4735). in this regard, Heckman and Kautz (2012, p. 451), said that the school, job market and many other domains are concerned for the more value addition to the students with personality traits, goals, motivations, and preferences.

Moreover, the soft skills are not only related to the interpersonal traits rather these qualities and competencies can be transferable to the wider range of economic and industrial context (Hurrell, 2016; Deloitte Access Economics, 2017). In addition, the existence in such a wider perspective enables the graduates to contribute to the knowledge-driven economy, earning efficiency and competencies using competitive knowledge, skills and capabilities. Because the upgraded knowledge, skills, abilities and pro-activity of employees can the expected employability which is treated as competitive advantages in the developed economies (Brown, Green, Lauder, 2001). In this regard, students' self-motivation is the influential source to achieve these skills with knowledge practices. Besides, the academic institutions and employers play stronger role to enhance employability by providing opportunity to earn soft skills and make them ready to get the desired job. Furthermore, this study would be beneficial as guidelines of career path from the both individual and institutional perspectives. 


\section{Implications}

The outcome this study suggested that it is essential to enhance the scope of learning and acquiring soft skills for the business graduates because it has high influence on the enhancing employability capacity. Thus, it is also recommended that to consider leadership, adaptability, team work, time management and creativity are the boost-up factors to develop soft skills for business graduates in Bangladesh. These skills have very high correlation to employability business graduates. This study also focuses on the influential role players in building soft skills such as self-learning, family learning, academic education, friends and classmates, professional institutions, employers and colleagues. Among them the self-motivations and family learning have direct impact on employability enhancement. The overall study presents a critical analytical and contributory insight of nine different soft skills and how does the graduates can acquire these for successfully facing the challenging job environment.

This study can be helpful as pathway for academic business programs of university, college or even the bottom-line levels. The business education modules can be enriched by adopting these trendy and ever learning soft skills with emphasizing the role players' contributions. Hence, the business graduates need to accelerate their communication with effective mode of interpersonal skills to stakeholders, so they require more project/team works and industrial visits in academic arena. Similarly, the group work and study may help them to find out the problem-solving techniques, being more adjustable to work, lead the others and managing time effectively. Moreover, the above practices make them to be more creative and self-dependent and maintain proper work ethics. Furthermore, the findings of this study might be encouraging to do further research or project works for the university and college students.

\section{Conclusion}

From the above discussion, it can be said that this is the high time to incorporate soft skills and relevant training in the business education programs as early as possible. In addition to it is the pragmatic need demanded by many business organizations. Robles et. al., (2012) identified the top 10 soft skills perceived as the most important by business executives: integrity, communication, courtesy, responsibility, social skills, positive attitude, professionalism, flexibility, teamwork, and work ethic. This study attempted to explore different trendy soft skills and correlation among them. So, here it is proved that soft skills have great influence on the enhancement of business graduate's employability. The leadership has the highest significant relationship with employability which includes empathy, selflessness, agility, listening, humility, cultural intelligence, authenticity, versatility, generosity and trust. Besides, adaptability, team work, time management, creativity, communication, work ethics, problem solving and interpersonal skills. The descriptive statistics shows that business graduates give more emphasize on adaptability, interpersonal skills and communication. Most of the data have been collected from the corporate house and educational institutions that's why they realize the importance of good communication with stakeholders along attractive interpersonal skills and the balanced adjustment to workplace. Moreover, the purpose of the study is not only to manifest the business graduates rather providing a pragmatic vision to other disciplines. Furthermore, the findings of the research try to show the insight of our existing business education curriculum and provide the guidelines to the educational leaders, managers and policy makers that how it could be updated by the successful implementation of soft skills.

\section{Limitations and Future Research}

The present study covers the synergetic effects of different soft skills on employability of business graduates in Bangladesh. There are some limitations found in this study that graduate respondents are only limited to business programs. Depending on that particular area, the findings can't be generalized to all. So, the future research would like to express the desire to endorse more pragmatic information about both business and non-business graduates including cognitive and qualitative job characteristics. Therefore, the future study might be helpful to make comparison about how does the academic paradigm influence to groom up relevant soft skills into students. In addition to more 
economic and behavioural aspects would be incorporated that have sophisticated influence in developing soft skills.

\section{References}

AACSB International (2012). Eligibility procedures and accreditation standards for business accreditation. (Revised: January 31, 2012). Tampa, FL: AACSB International.

Abraham, S. E., \& Karns, L. A. (2009). Do business schools value the competencies that businesses value?. Journal of Education for Business, 84(6), 350-356.

Ahlin, B., M. Drnovsek and R. Hisrich, (2014). Entrepreneurs' creativity and firm innovation: The moderating role of entrepreneurial self-efficacy. Small Business Economics, 43(1): 101-117.

Al-Alawneh, M.K., (2014). Measuring students' employability skills as they are perceived at Yarmouk University. Canadian Social Science, 10(1): 10-20.

American Management Association. (2012). Critical Skills Survey. Retrieved from: http://www.amanet.org/uploaded/2012-Critical-Skills-Survey.pdf. (accessed 30 November 2020).

Bacon, D. R., \& Anderson, E. S. (2004). Assessing and enhancing the basic writing skills of marketing students. Business Communication Quarterly, 67(4), 443-454.

Apparaju, H. (2016). How effective are the persuasive and other communication abilities of MBA students in India: Implications for business communication courses? IUP Journal of Soft Skills, 10(3), 24-47.

Armstrong, G., \& Kotler, P. (2012). Marketing: An introduction (1 $11^{\text {th }}$ ed.). Englewood Cliffs, NJ: Prentice-Hall.

Artess, J., Hooley, T., \& Bourne, R. M. (2017). Employability: A review of the literature 2012 to 2016.

Bateman, T. S., \& Crant, J. M. (1993). The proactive component of organizational behavior: A measure and correlates. Journal of organizational behavior, 14(2), 103-118.

Bedwell, W. L., Fiore, S. M., \& Salas, E. (2014). Developing the future workforce: An approach for integrating interpersonal skills into the MBA classroom. Academy of Management Learning \& Education, 13(2), 171-186.

Bedwell, W. L., Wildman, J. L., DiazGranados, D., Salazar, M., Kramer, W. S., \& Salas, E. (2012). Collaboration at work: An integrative multilevel conceptualization. Human Resource Management Review, 22(2), 128-145.

Beeri, I., R. Dayan, E. Gadot and S.B. Werner, 2013. Advancing ethics in public organizations: The impact of an ethics program on employees' perceptions and behaviours in a regional council. Journal of Business Ethics, 112(1): 59-78.

Bell III, T. J., Anderson, T., Conner, C., \& Severance, J. (2016). Does leadership style affect the academic performance of undergraduate business students? An empirical study. An Empirical Study (june 10, 2016). TJ Bell III, T. Anderson, C. Conner, and J. Severance. Does Leadership Style Affect the Academic Performance of Undergraduate Business Students, 112-125.

Bennis, W., \& O'Toole, J. (2005). How business schools lost their way. Harvard Business Review, 83(5),96-104.

Boyatzis, R., \& Boyatzis, R. E. (2008). Competencies in the 21 st century. Journal of management development.

Broadbear, J. T. (2003). Essential elements of lessons designed to promote critical thinking. Journal of Scholarship of Teaching and Learning, 3(3), 1-8.

Brodowsky, G., \& Anderson, B. (2003). Student perceptions of communication skills: Writing, presentations, and public speaking. Journal of the Academy of Business Education, 4, 13-22.

Brown, P., Green, A., \& Lauder, H. (2001). High skills: Globalization, competitiveness, and skill formation: globalization, competitiveness, and skill formation. OUP Oxford.

Cai, Z., Guan, Y., Li, H., Shi, W., Guo, K., Liu, Y., ... \& Hua, H. (2015). Self-esteem and proactive personality as predictors of future work self and career adaptability: An examination of mediating and moderating processes. Journal of Vocational behavior, 86, 86-94. 
Chapman, K. J., Meuter, M. L., Toy, D., \& Wright, L. K. (2010). Are student groups dysfunctional? Perspectives from both sides of the classroom. Journal of Marketing Education, 32(1), 3949.

Chaudhry, A. S., Khoo, C., Wu, P., \& Chang, Y. (2008). Trends in LIS education: coverage of soft skills in curricula. Journal of Librarianship and Information Studies, 66(2008), 1-13.

Claxton, G., Costa, A. L., \& Kallick, B. (2016). SOFT SKILLS. Educational leadership.

Colman, B., \& Willmot, P. (2016). How soft are 'Soft Skills' in the engineering profession?

Crane, F. G. (2004). The teaching of business ethics: An imperative at business schools. Journal of Education for Business, 79(3), 149-151.

Crowne, K. A. (2019). Investigating antecedents of transformational leadership in students. Journal of International Education in Business.

Cullen, K.L., B.D. Edwards, W.C. Casper and K.R. Gue, (2014). Employees' adaptability and perceptions of change-related uncertainty: Implications for perceived organizational support, job satisfaction, and performance. Journal of Business and Psychology, 29(2): 269-280.

Datar, S. M., Garvin, D. A., \& Cullen, P. G. (2010). Rethinking the MBA: Business education at a crossroads. Boston, MAL: Harvard Business Press.

Day, D. V. (2001). Leadership development: a review in context. Leadership Quarterly, 11, 581613. Directions for Institutional Research, 149, 53-64.

DTI (2001), Work-Life Balance: The Business Case, Department of Trade and Industry, London.

Dunne, D., \& Martin, R. (2006). Design thinking and how it will change management education: An interview and discussion. Academy of Management Learning \& Education, 5(4), 512-523.

Economics, D. A. (2017). Soft skills for business success. Deloitte Access Economics, Sydney). [Online]. Available from. https://www2.deloitte.com/au/en/pages/economics/articles/softskills-business-success.html (accessed 16 January 2018)

Erni, T. and Suhana, (2015). Employability skill readiness among business' students. International Journal of Science and Research, 4(8), 2319-7064.

Ettington, D. R., \& Camp, R. R. (2002). Facilitating transfer of skills between group projects and work teams. Journal of Management Education, 26(4), 356-379.

European Commission (2013), "High level group on the modernisation of higher education. Report to the European commission on improving the quality of teaching and learning in Europe's higher education institutions", available at: http://ec.europa.eu/education/library/reports/ modernisation_en.pdf (accessed 13 February 2018).

European Commission (EC) (2012a) An Agenda for New Skills and New Jobs in Europe: Pathways towards Full Employment [online] http://ec.europa.eu/research/social-sciences/pdf/newskilsand-jobs-in-europe en.pdf (accessed 12 January 2018).

European Commission (EC) (2012b) Rethinking Education Strategy: Investing in skills for better Socio-Economic Outcomes [online] http://ec.europa.eu/education/news/rethinking/ com669_en.pdf (accessed 12 January 2018).

Fekula, M. (2011). Managerial creativity, critical thinking, and emotional intelligence: Convergence in course design. Business Education Innovation Journal, 3, 92-102.

Fotopoulos, C. \& Psomas, E. (2008). The use of quality management tools and techniques in ISO 9001:2000 certified companies: the Greek case. International Journal of Productivity \&Performance Management, 58(6), 564-580.

Freeman, R. E., Stewart, L., \& Moriarty, B. (2009). Teaching business ethics in the age of Madoff. Change: The Magazine of Higher Learning, 41(6), 37-42.

Gentile, M. C. (2010). Turning values into action. Stanford Social Innovation Review, 8(4), 43-47.

Gerhardt, T. (2019). An analysis of the impact of a leadership intervention on an undergraduate workbased learning project for human resource management students. Journal of Work-Applied Management. 11(1), 53-62.

Gibb, S. (2014). Soft skills assessment: Theory development and the research agenda. International Journal of Lifelong Education, 33(4), 455-471.

Glenn, J. L. (2008). The "new" customer service model: Customer advocate, company ambassador. Business Education Forum, 62(4), 7-13. 
Gray, F. E. (2010). Specific oral communication skills desired in new accountancy graduates. Business communication quarterly, 73(1), 40-67.

Grugulis, I. (2003). Putting skills to work: learning and employment at the start of the century. Human Resource Management Journal.13(2): 3-12.

Grugulis, I., \& Vincent, S. (2009). Whose skill is it anyway? 'soft'skills and polarization. Work, employment and society, 23(4), 597-615.

Hair, J. F., Sarstedt, M., Ringle, C. M., \& Mena, J. A. (2012). An assessment of the use of partial least squares structural equation modeling in marketing research. Journal of the academy of marketing science, 40(3), 414-433.

Hanaysha, J. (2016). Examining the effects of employee empowerment, teamwork, and employee training on organizational commitment. Procedia-Social and Behavioural Sciences, 229(298-306), 298-306.

Hansen, R. S. (2006). Benefits and problems with student teams: Suggestions for improving team projects. Journal of Education for Business, 82, 11-19.

Harris, H. (2008). Promoting ethical reflection in the teaching of business ethics. Business ethics: A European review, 17(4), 379-390.

Hart Research Associates. (2009). Raising the bar: Employers' views on college learning in the wake of the economic downturn. Washington, D.C: Hart Research Associates.

Harvey, C. R. (2000). The drivers of expected returns in international markets. Available at SSRN 795385. (accessed 13 November 2020).

Hasbulloh, (2011). Basics of education. Jakarta: PT Raja Grafindo Persada.

Haselberger, D., Oberheumer, P., Perez, E., Cinque, M., \& Capasso, D. (2012). Mediating Soft Skills at Higher Education Institutions, Handbook of ModEs Project. Education and Culture DG Lifelong Learning Programme, European Union, Brussels.

Hashemizadeh, H. (2006). The relationship between time management behavior and job stress in medical surgical unit'head nurses of Shahid Beheshti Medical Sciences university. The quarterly Journal of Fundamentals of mental health, 29(8), 56-51.

Haws S. (2002), The Soft Skills of Business English, Article 28, September 2002.

Hazzan, O., \& Har-Shai, G. (2013, March). Teaching computer science soft skills as soft concepts. In Proceeding of the 44th ACM technical symposium on Computer science education (pp. 59-64).

Hellsten, L.M. (2012), "What do we know about time management? A review of the literature and a psychometric critique of instruments assessing time management", in Stoilov, T. (Ed.), Time Management, InTech, pp. 1-27, available at: www.intechopen.com/books/timemanagement/ (accessed 13 November 2020).

Helyer, R., \& Lee, D. (2014). The role of work experience in the future employability of higher education graduates. Higher Education Quarterly, 68(3), 348-372.

Hemming, H. E. (2000). Encouraging critical thinking: "But... what does that mean?" Journal of Education, 35(2), 173.

Herrington, M., Kew, J., \& Kew, P. (2010). Global entrepreneurship monitor. Retrieved March, 28, 2015.

Hoegl, M., K.P. Parboteeah and M. Muethel, (2012). Cross-national differences in managers' creativity promoting values. Management International Review, 52(4): 565-595.

Hommrichhausen, E. (2002), The effective engineer - the soft skills, proceedings of 5th international colloquium on engineering education, South Carolina, 2002, October 24-27, Available at http://www.uri.edu/iep/colloquia/2002/effe ctive_engineer.pdf (accessed 13 November 2020).

Hughes, R. L., \& Jones, S. K. (2011). Developing and accessing college student teamwork skills. New Directions for Institutional Research, 2011(149), 53-64.

Hurrell, S. A. (2016). Rethinking the soft skills deficit blame game: Employers, skills withdrawal and the reporting of soft skills gaps. Human Relations, 69(3), 605-628. 
Innabi, H., \& El Sheikh, O. (2007). The change in mathematics teachers' perceptions of critical thinking after 15 years of educational reform in Jordan. Educational Studies in Mathematics, 64(1), 45-68.

ISFOL (2012) Rapporto ISFOL 2012, Le competenze per l'occupazione e la crescita, Roma, ISFOL. Jamison, D. (2010). Leadership and Professional Development: An Integral Part of the Business Curriculum. Business Education Innovation Journal, 2(2).

Jelphs, K. (2006). Communication: Soft skill, hard impact? Clinician in Management, 14, 33-37.

Jiang, Z. (2017). Proactive personality and career adaptability: The role of thriving at work. Journal of Vocational Behavior, 98, 85-97.

John, J. (2009). Study on the nature of impact of soft skills training programme on the soft skills development of management students. Pacific Business Review, 10(12), 19-27.

Kachelmeier, S.J., B.E. Reichert and M.G. Williamson, (2008). Measuring and motivating quantity, creativity, or both. Journal of Accounting Research, 46(2): 341-373.

Kerin, R., Hartley, S., \& Rudelius, W. (2012). Marketing (11th ed.). New York, NY: McGrawHill/Irwin.

Kerr, C. \& Lloyd, C. (2008) Pedagogical learnings for management education: Developing creativity and innovation. Journal of Management and Organization, 14, 486-503.

Kirby, D. \& Romine, J. (2009). Develop oral presentation skills through accounting curriculum design and course-embedded assessment. Journal of Education for Business, 85, 172-179.

Klaus, P. (2010). Communication breakdown. California Job Journal, 28, 1-9.

Kleckner, M. J., \& Marshall, C. R. (2014). Critical communication skills: Developing course competencies to meet workforce needs. The Journal of Research in Business Education, $56(2), 59$.

Koen, J., Klehe, U. C., \& Van Vianen, A. E. (2012). Training career adaptability to facilitate a successful school-to-work transition. Journal of Vocational Behavior, 81(3), 395-408.

Landsman, J., \& Gorski, P. (2007). Countering standardization. Educational Leadership, 64(8), 4041.

Latham, G., Latham, S. D., \& Whyte, G. (2004)å. Fostering integrative thinking: Adapting the executive education eodel to the MBA program. Journal of Management Education, 28: 318.

Likert, R. (1961). New patterns of management. New York: McGraw-Hill.

Liming, Z., Tong, S., and Raihana, S. (2014). Importance of Soft Skills for Education and Career Success. International Journal for Cross-Disciplinary Subjects in Education (IJCDSE), 2(2): 1036-1042.

Lord, R. G., \& Hall, R. J. (2005). Identity, deep structure and the development of leadership skill. The Leadership Quarterly, 16(4), 591-615.

Lowry, D.: 2003, An Investigation of Student Moral Awareness and Associated Factors in Two Cohorts of an Undergraduate Business Degree in A British University: Implications for Business Ethics Curriculum Design_, Journal of Business Ethics 48(1), 7-13.

MacCann, C., Fogarty, G. J., \& Roberts, R. D. (2012). Strategies for success in education: Time management is more important for part-time than full-time community college students. Learning and Individual Differences, 22(5), 618-623.

Mansell, W. (2006). Diploma to plug the "soft skills" gap. Times Educational Supplement, 4673, 4.

Mansour, B., \& Dean, J. C. (2016). Employability skills as perceived by employers and university faculty in the fields of human resource development (HRD) for entry level graduate jobs. Journal of Human Resource and Sustainability Studies, 4(01), 39-49.

Marigliano, M., \& Russo, M. J. (2011). Foster Preschoolers' Critical Thinking and Problem Solving through Movement. YC: Young Children, 66(5), 12-13.

McDonald, G. M. (2004). A case example: Integrating ethics into the academic business curriculum. Journal of Business Ethics, 54(4), 371-384.

Meenu, W. and R. W. Kumar. (2009). "Developing Soft Skill in Students." The International Journal of Learning 15(12), 200-214. 
Messum, D., Wilkes, L., \& Jackson, D. (2015). What employability skills are required of new health managers? Asia Pacific Journal of Health Management, 10(1).

Mitchell, G. W., Skinner, L. B., \& White, B. J. (2010). Essential Soft Skills for Success in the Twenty-First Century Workforce as Perceived by Business Educators. Delta Pi Epsilon Journal, 52(1).

National Association of Colleges and Employers. (2001). Resource mining: Skills you'll need to get a job. Retrieved from http://careerplanit.com/resource/article.asp?subid=3\&artid=5 (accessed 13 November 2020).

National Network of Business and Industry Associations (2014). Common employability skills. A foundation for success in the workplace: the skills all employees need, no matter where they work. Retrieved from https://www.google.com/url?sa $=\mathrm{t} \& \mathrm{rct}=\mathrm{j} \& \mathrm{q}=\& \mathrm{esrc}=\mathrm{s} \&$ source=web\& $\mathrm{cd}=1 \& \mathrm{cad}=\mathrm{rja} \&$ uact $=$ 8\&ved=2ahUKEwjnjPGSyPfgAhUGxYsKHc7BB48QFjAAegQICRAC\&url=https\%3A\% 2F\%2Fs3.amazonaws.com\%2Fbrt.org\%2Farchive\%2FCommon\%2520Employability_asin gle_fm.pdf\&usg=AO vVaw0L2J2RV1g1MBu3KedkuQIj (accessed 13 November 2020).

Nolan-Arañez, S. I., \& Ludvik, M. B. (2018). Positing a framework for cultivating spirituality through public university leadership development. Journal of Research in Innovative Teaching \& Learning, 11(1), 94-109.

Nusrat, M., \& Sultana, N. (2019). Soft skills for sustainable employment of business graduates of Bangladesh. Higher Education, Skills and Work-Based Learning.

O"ncel, L. (2014). Career Adapt-Abilities Scale: Convergent validity of subscale scores. Journal of Vocational Behavior, 85, 13-17.

Payne, J. (2000). The unbearable lightness of skill: the changing meaning of skill in UK policy discourses and some implications for education and training. Journal of Education Policy. 15(3):353- 369 .

Petrick, J.A., W. Cragg and M. Sañudo, (2011). Business ethics in North America: Trends and challenges. Journal of Business Ethics, 104(S1): 51-62.

Pereira, O. P., \& Costa, C. A. A. T. (2017). The importance of soft skills in the university academic curriculum: The perceptions of the students in the new society of knowledge.

Perreault, H. (2004). "Business Educators Can Take a Leadership Role in Character Education." Business Education Forum 59(1):23-24.

Pfeffer, J., \& Fong, C. T. (2002). The end of business schools? Less success than meets the eye. Academy perspectives from both sides of the classroom. Journal of Marketing Education, 32, 39-49.

Pittenger, K. K. S., Miller, M. C. \& Mott, J. (2004). Using real-world standards to enhance student's presentation skills. Business Communication Quarterly, 67 (3), 327-336.

Remedios, R. (2012). The role of soft skills in employability. International Journal of Management Research and Reviews, 2(7), 1285.

Riebe, L., Roepen, D., Santarelli, B., \& Marchioro, G. (2010). Teamwork: effectively teaching an employability skill. Education+ Training, 52(6/7), 528-539.

Robles, M.M., (2012). Executive perceptions of the top 10 soft skills needed in today's workplace. Business Communication Quarterly, 75(4): $453-465$.

Robotham, D., \& Julian, C. (2006). Stress and the higher education student: A critical review of the literature. Journal of Further and Higher Education, 30, 107-117.

Rocha, M., (2012). Transferable skills representations in a Portuguese college sample: Gender, age, adaptabilityand vocational development. European Journal of Psychology of Education, 27(1): 77-90.

Salleh, K. M., Sulaiman, N. L., Mohamad, M. M., \& Sern, L. C. (2017). Assessing soft skills components in science and technology programmes within Malaysian Technical Universities. Songklanakarin Journal of Science \& Technology, 93(3).

Sandholtz, J. H., Ogawa, R. T., \& Scribner, S. P. (2004). Standards gaps: Unintended consequences of local standards-based reform. Teachers College Record, 106(6), 1177-1202. 
Sangamitra, B., \& Priya, N. S. (2015). Employability With Soft Skills: An Overview. International Journal of Multidisciplinary Research and Development, 2(3), 296-298.

Sapp, D. \& Zhang, Q. (2009). Trends in industry supervisors' feedback on business communication internships. Business Communication Quarterly, 72, (3), 274-288.

Savickas, M. L., \& Porfeli, E. J. (2012). The Career Adapt-Abilities Scale: Construction, reliability, and measurement equivalence across 13 countries. Journal of Vocational Behavior, 80, 744 747.

Schlee, R. P., Curren, M. T., Harich, K. R., \& Kiesler, T. (2007). Perception bias among undergraduate business students by major. Journal of Education for Business, 82, 169-177.

Schön, D. A. (1987). Educating the reflective practitioner. school-to-work transition. Journal of Vocational Behavior, 81, 395-408.

Scriven, M., \& Paul, R. (2007). Defining critical thinking. The Critical Thinking Community: Foundation for Critical Thinking. Retrieved from http://www.criticalthinking.org/aboutCT/define_critical_thinking.cfm (accessed 13 November 2020).

Shaffer, D. W. (2004). Pedagogical praxis: the professions as models for post-industrial education. Teachers College Record, 10, 1401-1421.

Shah, M., L. Grebennikov and C.S. Nair, (2015). A decade of study on employer feedback on the quality of university graduates. Quality Assurance in Education, 23(3): 262-278.

Shahbaz, M. M. (2016). Academia-industry linkages gap analysis survey. Lahore, Pakistan: Career Advisory and Assessment Services.

Shayanka, P., Breyer, Y.A. and Wood, L.N. (2016), "Transforming the economics curriculum by integrating threshold concepts", Education + Training, 58(5), 492-509.

Sheriff, I. H. N., Ahmed, F., Jivraj, N., Wan, J. C., Sampford, J., \& Ahmed, N. e. (2017). Studentled leadership training for undergraduate healthcare students. Leadership in Health Services, 30(4), 428-431.

Snyder, L. G., \& Snyder, M. J. (2008). Teaching critical thinking and problem-solving skills. The Journal of Research in Business Education, 50(2), 90.

Succi, C. (2019). Are you ready to find a job? Ranking of a list of soft skills to enhance graduates' employability. International Journal of Human Resources Development and Management, 19(3), 281-297.

Sutton, N. (2002). “Why Can't We All Just Get Along?" Computing Canada 28(16):20.

Tamkin, P., Cowling, M. \& Hunt, W. (2008). People and the Bottom Line. London: The Work Foundation

Taylor, E., (2016). Investigating the perception of stakeholders on soft skills development of students: Evidence from South Africa. Interdisciplinary Journal of E-Skills and Lifelong Learning, 12(1): 1-18.

Thompson, S. A., \& Miller, K. L. (2018). Disruptive trends in higher education: Leadership skills for successful leaders. Journal of Professional Nursing, 34(2), 92-96.

Timm, J. A. (2005). Preparing students for the next employment revolution. Business Education Forum, 60, 55-59.

Truong, H., \& Laura, R. (2015). Essential Soft Skills for Successful Business Graduates in Vietnam. Sociology Study, 5(10), 759-763.

Turner J. (2020, April 28), "Why Self-Learning Matters in the 21st Century". The Thrive Global Community [online] https://thriveglobal.com/stories/why-self-learning-matters-in-the-21stcentury/ (accessed 10 November 2020). Vocational Behaviour, 98, 85-97.

Wang, S., Peck, K. L., \& Chern, J. (2010). Difference in time influencing creativity performance between design and management majors. International Journal of Technology \& Design Education, 20, 77-93.

Wang, Y.-F. and C.-T. Tsai, (2014). Employability of hospitality graduates: Student and industry perspectives. Journal of Hospitality \& Tourism Education, 26(3): 125-135.

Watts M \& Watts RK (2008), "Developing soft skills in students" retrieved from http://108.cgpublisher.com/proposals/64/in dex_htm (accessed 10 November 2020). 
Weinstein, J., L. Morton, H. Taras and V. Reznik, (2013). Teaching teamwork to law students. Journal of Legal Education, 63(1): 36-64.

Weinzimmer, L. G., Michel, E. J., \& Franczak, J. L. (2011). Creativity and firm-level performance: The mediating effects of action orientation. Journal of Managerial Issues, 62-82.

Wellington, J. K. (2005). The" soft skills" of success. Vital speeches of the day, 71(20), 628.

Wheeler, R. (2016). Soft skills-the importance of cultivating emotional intelligence. AALL Spectrum, 20(3), 28.

Wilhelm, W. J. (2004). Determinants of moral reasoning: Academic factors, gender, richness of life experiences, and religious preferences. Delta Pi Epsilon Journal, 46, 105-121.

Williams, L.K. and S.J. McGuire, (2010). Economic creativity and innovation implementation: The entrepreneurial drivers of growth? Small Business Economics, 34(4): 391-412.

Wong, D. (2007). Beyond control and rationality: Dewey, aesthetics, motivation, and educative experiences. Teachers College Record, 109(1), 192-220.

Yorke, M. (2006). Employability in higher education: what it is - what it is not. Retrieved from Higher Education Academy website: https://www.heacademy.ac.uk/knowledgehub/employability-highereducation-what-it-what-it-not. (accessed 12 November 2020).

Young, M. \& Murphy, W. (2003). Integrating communications skills into the marketing curriculum: A case study. Journal of Marketing Education, 25 (1), 57-70. 